\title{
Effect of Butyrylated Arrowroot Starch to the Digesta Profile and Molar Ratio SCFA
}

\author{
Damat $^{1}$ \\ ${ }^{1}$ Department of Food Science and Technology, Faculty of Agriculture and Animal Husbandry, University of \\ Muhammadiyah Malang, East Java, Indonesia \\ Correspondence: Damat, Department of Food Science and Technology, Faculty of Agriculture and Animal \\ Husbandry, University of Muhammadiyah Malang, Jl. Raya Tlogomas No. 246 Malang, East Java 65144, \\ Indonesia. E-mail: damatumm@yahoo.co.id
}

\author{
Received: February 20, 2013 Accepted: March 19, 2013 Online Published: March 28, 2013 \\ doi:10.5539/jfr.v2n2p144 \\ URL: http://dx.doi.org/10.5539/jfr.v2n2p144
}

\begin{abstract}
The research was conducted to determine the effects of Butyrylated Arrowroot Starch (BAS) to the digesta profile and Short Chain Fatty Acids (SCFA) molar ratio. The research was conducted by using simple complete randomized design (CRD). The treatment tested was feed type, which consists of 5 levels, namely natural arrowroot starch, BAS with Degree of Substitution (DS) $0.053 ; 0.120 ; 0.187$ and AIN93 natural feed. The study was conducted by using 30 Sprague Dawley rats, which were divided into 5 groups, each group consisting of 6 tails. Feeding treatments were given from dayseven until day 33. On day-34 analysis was conductedof the digesta profile and the SCFA molar ratio. Based on the analysis results, it is known that BAS feeding increased digesta weight, decreased digesta $\mathrm{pH}$ and increased digesta water content when compared with the AIN93 standard feed. Largest amount of digesta, lowest digesta $\mathrm{pH}$, and highest water content of digesta, respectively $7.19 \mathrm{~g}, 6.53$ and $91.23 \%$, wasobtained from rats fed BAS with DS 0.187 . The molar ratio of butyric acid in digesta also increased along with the increasing BAS DS.
\end{abstract}

Keywords: butyrylated arrowroot starch, digesta profile, short chain fatty acids

\section{Introduction}

Cancer is a deadly desease, ranking second in the leading causes of death in the world. According to WHO data in 2005 , as many as $7.5 \%$ of deaths around the world were caused by cancer. By 2015, this is expected to rise to $9.1 \%$. One type of cancer that is often deadly is colon cancer. Many theories have stated that the high prevalence of colon cancer is associated with a low fiber diet and a high intake of meat (Bingham, 1990). Surprisingly Japan, a developed country with relatively low fiber consumption (11 g/day), has a lower incidence of colon cancer. This fact may be caused by a diet high in Resistant Starch (RS) which has a role in the protection against colon cancer (Bingham, 1990). This is supported by other data showing that when the digestion and absorption of starch are efficient, less amounts of starch reache the colon,increasing the chances for colon cancer. Food consumption that contains lots of resistant starch can increase the production of short chain fatty acids in the large intestine (colon).

Resistent Starch is defined as starch and the byproduct of starch that cannot be absorbed by the small intestine of healthy individuals (Asp, 1992; Marsono, 2005). Resistent Starch is known to have beneficial physiological effects for people who consume it (Nugent, 2005). The physiological effects include (i) helps prevent colon cancer, (ii) has a hypoglycemic effect, (iii) acts as a prebiotic, (iv) has a hypolipidemic effect and (v) can increase the absorption of minerals. According to Bird et al. (2006), Resistent starch consumption can improve the colon health relative index, which includes an increase in bulk digesta and SCFA molar ratio as well as decrease digesta $\mathrm{pH}$.

SCFA have beneficial physiological effects for the body as well. SCFA are known to inhibit cholesterol synthesis in the liver, resulting in the decrease of the blood plasmas total cholesterol, VLDL, IDL, and LDL cholesterol and triglycerides (Tester et al., 2006). The cholesterol-decreasing effect by Resistent Starch is highly dependent on the LDL receptor, mRNA levels of cholesterol 7 ahydroxylase, steroid excretion with feces and butyric acid production rate. According to Annison et al. (2003), giving different types of Resistent Starch to mice can produce different concentrations of SCFA. Feeding the mice with the diet containing acetate corn 
starch increased the concentration of acetic acid in the colon digesta from 37.1 to 142.0 ๆmol. Feeding the mice with the diet containing propionate corn starch increased the concentration of propionic acid in the colon digesta from 12.1 to 95.6 mol. Restricting feed containing corn starch butyrate c increased the concentration of butyric acid in the colon digesta from 8.1 to $93.3 \eta \mathrm{mol}$. In this state, the modified starch by esterification can serve as carriers of SCFA esterified to the starch molecules. From these issues, it is important to research the effect of butyrylated arrowroot starch (BAS) to the digesta profile and molar ratio SCFA.

\section{Materials and Method}

For this research butyrylated arrowroot starch with degrees of substitution (DS) $0.053,0.120$, and 0.187 , as well as standard feed AIN93 was given to the test animals. The main tools used were glass (Pyrex), analytical balance (Sartorius), weights of test animals, sonde, Vortex, Micro pipette (Sacorex, Isba SA, Switzerland, Acura adjustable micropipette 200-1000 $821 \mathrm{~mL}$ ) and chromatography gas (GC) GC-8A Brand Simadzu, with FID detector.

\subsection{Butyrylated Arrowroot Starch Preparation}

The butyrylated arrowroot starch (BAS) preparation was done with methods that have been developed by Damat (2008). A total of 100 grams of arrowroot starch was dispersed into $225 \mathrm{ml}$ of distilled water and then stirred for 60 minutes at $25^{\circ} \mathrm{C} .3 .0 \% \mathrm{NaOH}$ solution was added to the water/BAS mixture until the $\mathrm{pH}$ reached 10 . Then a butyric anhydride with concentrations of $10 \%, 15 \%$, and $20 \%$ was added with degrees of substitution 0.053 ; 0.120 , and 0.187 . While adding butyric anhydride, the $\mathrm{pH}$ wass maintained at 10 by adding $\mathrm{NaOH}$ solution $3 \%$. After the addition of butyric anhydride, the suspension was left to sit for 20 minutes. Furthermore, the $\mathrm{pH}$ of the suspension was decreased to 4.5 with a solution of $\mathrm{HCl} 0.5 \mathrm{~N}$. The suspension was washed to free any anhydride butyric residue. Washing was conducted three times by using aquades and ethanol, while the separation between the solids and the supernatant was conducted by using centrifuge. The solid obtained was dried at a temperature of $45^{\circ} \mathrm{C}$.

\subsection{Digesta Profile Testing}

The digesta profile analysis was conducted by using Sprague Dawley rats, with weights of 250-300 g, and the ages of 2-3 months. Before the rats were fed the treatment, rats were fed standard AIN93 for 6 days. Feeding was conducted in ad libitum. The rats were weighed each day to monitor growth. On day six, the rats were grouped, and divided into 5 groups, so that each group consisted of 6 rats with equal weights. Each group was fed a different concentration of treatment. These concentrations were: natural arrowroot starch, BAS with DS 0.053; BAS with DS 0.120, BAS with DS 0.187, and the control group was fed AIN93 standard feed.. The rats were housed individually (one tail / cage) for 6 days of adaptation and 28 days of treatment.

On the $34^{\text {th }}$ day, the digesta profile analysis was conducted. The analysis included $\mathrm{pH}$ digesta, digesta weight, digesta water content, and the molar ratio of SCFA, especially acetic acid, propionic acid and butyric acid. Water content analysis was conducted by using the oven method (AOAC, 1990). The weight of digesta was measured by using an analytical balance, and the digesta $\mathrm{pH}$ was measured with a $\mathrm{pH}$ meter. The analysis of SCFA was conducted by using chromatography gas (GC) GC-8A Brand Simadzu, with a FID detector. The column used was a glass column GP $10 \%$ SP $1200 / 1 \% \mathrm{H}_{3} \mathrm{PO}_{4}$ on $80 / 100$ chromosorb WAW column with length of 2 meters and a diameter of $3 \mathrm{~mm}$. Injector temperature was $220^{\circ} \mathrm{C}$, detector temperature was $220^{\circ} \mathrm{C}$, the column temperature was $1300^{\circ} \mathrm{C}$, the gas pressure was $\mathrm{H}_{2}=0.6 \mathrm{~kg} / \mathrm{cm}^{2}$, and the air pressure $=0.5 \mathrm{~kg} / \mathrm{cm}^{2}, \mathrm{~N}^{2}=1.25$ $\mathrm{kg} / \mathrm{cm}^{2}$ pressure. The carrier gas was $\mathrm{N}^{2}$ gas.

\subsection{Experimental Design}

The research was conducted using simple completely randomized design. The treatments tested the type of feed, which consisted of 5 levels, namely natural arrowroot starch, butyrylated arrowroot starch with degrees of substitution $0.053 ; 0.120 ; 0.187$ and AIN93 natural feed.

\section{Results and Discussion}

\subsection{Weight of Digesta}

Diet administration which arrowroot starch highly significant $(\alpha=0.01)$ to weighing digesta of Sprague Dawley rat. The rats who were given arrowroot starch-butyrate with a degree of substitution 0.187 had the highest weigts, totaling to $7.178 \mathrm{~g}$. This weight total significantly differed with the total weight of digesta of the rats who were fed AIN93 natural feed, natural arrowroot starch and arrowroot starch-butyrate with DS 0.053 and $0.120(\alpha=0.05)$ (Table 1). 
Several factors that can increase the digesta weight include resistant starch on fecal matter, which is not degraded, the ability of resistant starch to absorb water resulting in the increase of fecal water content, and increased bacterial cell mass due to fermentation of resistant starch. These results are similar to the results of research conducted by Bajka et al. (2006), which states that esterification can increase the weight of digesta on the caecum. Rats which was fed uncooked starch had higher digesta weight and were significantly different when compared to rats which were fed with starch esterification $(\alpha=0.05)$. This is because the starch had not been cooked, resulting in a higher resistant starch content, making it more difficult for emylolytic enzymes to hydrolyze in the small intestine. Similar results were also reported by Jenkins et al. (1998), which stated that the administration of dietary resistant starch type 2 and resistant starch type 3 on rats increased feces weightby $23 \%$.

\section{2 pH Digesta}

The Sprague Dawley rats that were fed butyrylated arrowroot starch with DS 0.187 had a pH of 6.93 and were not significantly different from digesta $\mathrm{pH}$ of rats fed butyrylated arrowroot starch with DS $0.120 ; 0.053$, natural arrowroot starch and AIN93 natural feed each with the $\mathrm{pH}$ of 6.95; 6.96; 6.96 and 6.99 (Table 1). This is because butyrylated arrowroot starch contains resistant starch. In the small intestine, resistant starch cannot be hydrolyzed by amylolytic enzymes and enter into the colon. In the colon, resistant starch would be a substrate for colonic microbes and produce short chain fatty acids, mainly acetic acid, butyric acid and propionate. All the acid are a kind of weak acid, therefore feeding rats a diet containing butyrylated arrowroot starch with varying DS, digesta $\mathrm{pH}$ was not significantly different.

These results are similar to the results of research conducted by Clarke et al. (2007), which stated that there was no difference between the digesta $\mathrm{pH}$ of volunteers who were given diets containing corn starch acetate, propionate corn starch and corn starch butyrate with digesta $\mathrm{pH}$ of volunteers who were given the control diet. The digesta $\mathrm{pH}$ of volunteers with the kind of dietary treatment totaled to $7.40,7.40,7.50$ and 7.40 . This is because the acid concentration produced from the fermentation process by colonic microbial activity is quite low, so it is not significant enough to decrease the $\mathrm{pH}$ of the digesta colon.

These results differ from the results of research conducted by Han et al. (2004), which stated that digesta pH of rats lowered when given feed containing resistant starch Kintoki, compared to those fed standard feed. Bajka et al. (2006) also reported that rats given a diet of natural starches feed had lower $\mathrm{pH}$ than rats fed with cooked starch feed. According to Sharp and Macfarlane (2000), short-chain fatty acids and lactic acids contribute to changes in $\mathrm{pH}$ value and produce a good environment for the growth of Lactobacilli and Bifidobacteria. Colonic $\mathrm{pH}$ is low and many Lactobacilli colonies can inhibit the proliferation of pathogenic bacteria, such as Escherichia coli strains or Clostridium sp.

Table 1. Weight, $\mathrm{pH}$, and water content of digesta of Sprague Dawley rats who were fed with butyrylated arrowroot starch with different degrees of substitutions

\begin{tabular}{|c|c|c|c|}
\hline Treatments & $\begin{array}{l}\text { Weight of } \\
\text { digesta }(g)\end{array}$ & $\mathrm{pH}$ & $\begin{array}{l}\text { The water content } \\
\text { of digesta }(\%)\end{array}$ \\
\hline Diet containing natural arrowroot starch & $1.159 \pm 0.072 \mathrm{a}$ & $6.96 \pm 0.120 \mathrm{~ns}$ & $87.62 \pm 2.411 \mathrm{~b}$ \\
\hline $\begin{array}{l}\text { Diet containing butyrylated arrowroot starch, } \\
\mathrm{DS}=0.053\end{array}$ & $4.434 \pm 0.133 \mathrm{c}$ & $6.96 \pm 0.191 \mathrm{~ns}$ & $88.87 \pm 2.890 \mathrm{c}$ \\
\hline $\begin{array}{l}\text { Diet containing butyrylated arrowroot starch, } \\
\text { DS }=0.120\end{array}$ & $5.674 \pm 0.124 \mathrm{~d}$ & $6.95 \pm 0.124 \mathrm{~ns}$ & $90.81 \pm 3.022 \mathrm{~d}$ \\
\hline $\begin{array}{l}\text { Diet containing butyrylated arrowroot starch, } \\
\text { DS }=0.187\end{array}$ & $7.178 \pm 0.211 \mathrm{e}$ & $6.93 \pm 0.211 \mathrm{~ns}$ & $91.23 \pm 2.990 \mathrm{e}$ \\
\hline Diet control (AIN93) & $3.303 \pm 0.113 b$ & $6.99 \pm 0.113 \mathrm{~ns}$ & $86.65 \pm 4.015 \mathrm{a}$ \\
\hline
\end{tabular}

The numbers followed by different letters in the same column indicate significantly different by LSD 5\%.

\subsection{The water Content of Digesta}

The administration of diets containing arrowroot starch had a highly significant influence $(\alpha=0.01)$ on water content of Sprague Dawley rats' digesta (Table 1). Rats fed butyrylated arrowroot starch with DS 0.187 had a digesta water content of $91.23 \%$, which was significantly $(\alpha=0.05)$ higher when compared to the digesta water content of rats which were fed with butyrylated arrowroot starch with DS 0.120, DS 0.053 and AIN93 natural feed. The higher DS of butyrylated arrowroot starch, the greater water content of digesta. The water content of digesta from rats fed with AIN93 natural feed had the lowest level, which is $86.65 \%$ butyrate greater water 
content digesta. This shows that butyrylated arrowroot starch has a binding ability to water higher than the natural arrowroot starch and feed standards. In addition it is known that the greater the value of DS of butyrylated arrowroot starch, the greater the ability to bind water.

Digesta water content is a reflection of the water holding capacity (WHC) of dietary components, especially polysaccharides. The water binding ability of the polysaccharide is determined by the chemical structure of polysaccharides, species and anatomical source material (Sembor et al., 1999; Kurniawati, 2003). These results are similar to results done by Cheng and Lai (2000) and Henningsson et al. (2002), in which the group of rats fed resistent Starches had feces with water content higher than compared to the other groups which were given feed containing no resistant starches. According to Marsono (2005), this property is important because resistant starches can reduce transit time of feces in the colon and increase feces weight.

\subsection{Molar Ratio of Short Chain Fatty Acids (SCFA)}

Based on the results of the statistical analysis, there is a significant effect $(\alpha=0.005)$, between the type of feed given with butyric acid and the molar ratio of rat's digesta. The rats which were given butyrylated arrowroot starch treatment had higher butyric acid molar ratios and were significantly different to those given the AIN93 natural feed. The rats which were given butyrylated arrowroot starch with SD 0.187 had a molar ratio of butyric acid digesta totaling $34.41 \%$ higher then compared with the molar ratio of butyrate digesta of rats which were given butyrylated arrowroot starch with SD 0.053; SD 0.120, natural arrowroot starch or with AIN93 natural feed (Table 2). The largest molar ratio of acetic acid (60.26\%) and lowest butyric acid ratio (10.04\%) were found in the results of giving AIN93 natural feed $t$ to the rats.

Based on these results it was known that there is a correlation that the higher the degree of substitution (DS) of butyrylated arrowroot starch, the higher ratio of butyric acid on rat digesta. Increasing the molar ratio of butyric acid showed that there was deesterification caused by microbial activity and residual starch fermentation in the colon. Acetate, butyrate, and total SCFA concentrations were higher when participants consumed RS compared with entry and NSP diets, but individual responses varied (McOrist et al., 2011). These results are similar to results of previous studies conducted by Annison et al. (2003), which stated that the use of starch butyrate from corn starch butyrate can increase the concentration of butyric acid in experimental animal colonscompared to using starch acetate or propionate starch from corn starch. According to Cummings and Bingham (1987) and Falony et al. (2000), butyrate has an important role against colon health. This is because butyrate not only functions as an energy source for the colonic epithelium, but also provides important effects on gene expression of colon cells. Besides, butyrate also has an important role in preventing colon cancer and colitis. Butyrate is known to have theability to inhibit the promotion phase of carcinogenesis (Bird et al., 2006).

Butyrate and other SCFA produced by bacterial fermentation of resistant starch (RS) promote human colonic health (McOrist et al., 2011). Of the major SCFAs, butyrate is of special interest because it is the preferred energy source for colonocytes and promotes a normal phenotype in these cells and hence may protect against cancer and other serious colonic diseases (Clarke et al., 2011). According to Brouns et al. (2002), butyric acid is not only able to inhibit colon cancer growth, but is also able to inhibit prostate cancer growth. The mechanism of resistant starch in preventing colon cancer is as follows: (i) Feces become liquid, and is easily removed from the colon, so the transit time in the colon is shorter. This will shorten the contact time between carcinogens with the colonic mucosa. (ii) butyric acid produced will maintain mucosal health and SCFA will stimulate the growth of beneficial bacteria present in the colon. Resistant starch has bulky quality so it will be easier to absorb water.

Tabel 2. Molar ratio of short chain fatty acid from rat digesta

\begin{tabular}{llll}
\hline \multicolumn{1}{c}{ Treatments } & $\begin{array}{l}\text { Molar ratio of } \\
\text { acetic acid (\%) }\end{array}$ & $\begin{array}{l}\text { Molar ratio of } \\
\text { propionate acid (\%) }\end{array}$ & $\begin{array}{l}\text { Molar ratio of } \\
\text { Butyric acid (\%) }\end{array}$ \\
\hline $\begin{array}{l}\text { Diet control (AIN93) } \\
\text { Diet containing natural arrowroot starch }\end{array}$ & $\begin{array}{l}60.23 \pm 3.94 \mathrm{~d} \\
25.98 \pm 2.65 \mathrm{c}\end{array}$ & $\begin{array}{l}29.67 \pm 2.10 \mathrm{c} \\
32.09 \pm 1.24 \mathrm{~d}\end{array}$ & $\begin{array}{l}10.11 \pm 0.62 \mathrm{a} \\
21.93 \pm 1.58 \mathrm{~b}\end{array}$ \\
$\begin{array}{l}\text { Diet containing butyrylated arrowroot starch, } \\
\text { DS = 0.053 }\end{array}$ & $39.92 \pm 2.82 \mathrm{a}$ & $36.83 \pm 1.66 \mathrm{e}$ & $23.25 \pm 1.54 \mathrm{c}$ \\
$\begin{array}{l}\text { Diet containing butyrylated arrowroot starch, } \\
\text { DS = 0.120 }\end{array}$ & $45.96 \pm 1.74 \mathrm{c}$ & $20.77 \pm 1.32 \mathrm{a}$ & $33.27 \pm 2.43 \mathrm{~d}$ \\
$\begin{array}{l}\text { Diet containing butyrylated arrowroot starch, } \\
\text { DS =0.187 }\end{array}$ & $40.97 \pm 2.26 \mathrm{~b}$ & $24.60 \pm 2.21 \mathrm{~b}$ & $34.42 \pm 5.52 \mathrm{~d}$ \\
\hline
\end{tabular}

The numbers followed by different letters in the same column indicate significantly different by LSD 5\%. 
According to Leng et al. (2001), the mechanism of colon cancer inhibition by butyric acid is as followed: (i) Butyrate potentially has anti-colon cancer qualities by inhibiting the growth of carcinogens and encouraging apoptosis. (ii) Butyrate will induce apoptosis and the expression of Insulin like Growth Fators Binding Protein-3 (IGFBP-3) through inhibition of Histone Deacetylase (HDAC). (iii) Insulin like Growth Fators (IGF)-II is inhibited by butyrate, through the Caspase- 3 action, but stimulated by butyrate induction of IGFBP-3. (iv) Butyrate will promote cell migration through HDAC-independent pathways and the IGF has an additional effect against this process. (v) IGF-II does not move to HDAC because it is inhibited by Trichostatin (TSA), and TSA will directly bind to HDAC.

The molar ratio of short-chain fatty acids are influenced by the type of carbohydrate consumed. According to Henningsson et al. (2002), rats that were given diet guar gum produced the highest ratio of propionic acid. When given feed with pectin, rats produced the highest ratio of acetic acid, whereas when was given corn starch with high amylose feed, rats produced the highest ratio of butyric acid. Besides short-chain fatty acid resulting fromfood fiber fermentation on the colon can also inhibit cholesterol synthesis (Anderson et al., 2000).

Acetic acid is a basic ingredient of the butyrate production process. According to Duncan et al. (2002), there are two synthesis process pathways on the microbial butyrate. In the synthesis process of butyrate, glucose degradation results from starch being converted to pyruvate and then converted to acetyl coenzyme A (CoA). Two molecules of acetyl coenzyme A (CoA) were converted to asetoasetil-CoA and then converted to butyryl-CoA. Next butyryl-CoA was converted to butyrate through two pathways, namely (i) kinase butyrate and (ii) through the butyryl-CoA: acetate-CoA transferase. According to Kleesen et al. (1997) various factors are known to affect the growth and colonic microbial fermentation results, such as oxidation-reduction potential, $\mathrm{pH}$, SCFA and lactate concentrations, along with the host's condition, which can include intestinal motility and the presence or absence of antimicrobial compounds, the interaction between bacterial metabolic, and changes in a species bacterial fermentation strategies.

\section{Conclusion}

Based on these results it can be concluded that the feeding of butyrylated arrowroot starch can increase the weight of digesta, decrease digesta $\mathrm{pH}$, and increase water content of digesta when compared with the standard AIN93 feeding. The Largest amount of digesta, lowest digesta $\mathrm{pH}$, and highest water content of digesta were obtained from Sprague Dawley rats that were fed butyrylated arrowroot starch. The molar ratio of butyric acid in digesta increased along with the increasing degree of substitution of butyrylated arrowroot starch.

\section{Reference}

Annison, G., Illman, R. J., \& Toping, D. L. (2003). Acetylated, propionylated or butyrylated starches raise large bowel short-chain fatty acids preferentially when fed to rats. J. Nutr., 133, 3523-3528.

AOAC. (1990). Official methods of analysis of the association of official analytical chemists (15th ed.). Vurginia.

Bajka, B. H., Topping, D. L., Cobiacdan, L., \& Clarke, J. M. (2006). Butyrylated starch is less susceptible to enzymic hydrolysis and increases large-bowel butyrate more than high-amylose maize starch in the rat. British J. of Nutrition, 96, 276-282. http://dx.doi.org/10.1079/BJN20061807

Bingham, S. A. (1990). Mechanisms and experimental and epidemiological evidence relating dietary fibre (non-starch polysaccharides) and starch to protection against bowel cancer. Procceding of the Nutrition Society, 49, 153-171. http://dx.doi.org/10.1079/PNS19900021

Bird, A. R., Brown, dan I. L., \& Topping, D. L. (2006). Low and high amylose maize starches acetylated by a commercial or a laboratory process both deliver acetate to the large bowel of rats. Food Hydrocolloids, 20, 1135-1140. http://dx.doi.org/10.1016/j.foodhyd.2005.12.009

Brouns, F., Kettlitz, B., \& Arrigoni, E. (2002). Resistant starch and "the butyrate revolution". Trends in Food Science \& Technology, 13, 251-261. http://dx.doi.org/10.1016/S0924-2244(02)00131-0

Cheng, H., \& Lai, M. H. (2000). Fermentation of resistant rice starch produces propionate reducing serum and hepatic cholesterol in rats. J. Nutr., 130, 1991-1995.

Clarke, J. A., Bird, A. R., Topping, D. L., \& Cobiac, L. (2007). Excretion of starch and esterified short-chain fatty acids by ileostomy subjects after the ingestion of acylated starches. Am J. Clin Nutr., 86, 1146-1151. http://dx.doi.org/10.3945/ajcn.111.017228 
Clarke, J. M., Topping, D. L., Christophersen, C. T., Bird, A. R., Lange, K., Saunders, I., \& Cobiac, L. (2011). Butyrate esterified to starch is released in the human gastrointestinal tract1-3. Am. J. Clin. Nutr., 94, 1276-1283.

Cummings, J. H., \& Bingham, S. A. (1987). Dietary fibre, fermentation and large bowel cancer. Cancer Surveys, 6, 601-621.

Damat, H., Marsono, Y., \& Cahyanto, M. N. (2008). Efek pH dan konsentrasi butirat anhidrida selama butirilisasi pati garut terhadap karakteristik pati-garut butirat. Journal Agritech, 28(2).

Duncan, S. H., Barcenilla, A., Stewart, C. S., Pryde, S. E., \& Flint, H. J. (2002). Acetate utilization and butyryl coenzyme A $(\mathrm{CoA})$ :acetate-CoA transferase in butyrate-producing bacteria from the human large intestine. Appl. Environ. Microbiol., 68(10), 5186-5190. http://dx.doi.org/10.1128/AEM.68.10.5186-5190.2002

Falony, G., Vlachou, A., Verbrugghe, K., \& Vuyst, L. D. (2006). Cross-feeding between Bifidobacterium longum BB536 and acetate-converting, butyrate-producing colon bacteria during growth on gligofructose. Appl. Environ. Microbiol, 7835-7841. http://dx.doi.org/10.1128/AEM.01296-06

Han, K., Sekikawa, M., Shimada, K., Sasaki, K., Ohba, K., \& Fukushima, M. (2004). Resistant starch fraction prepared from kintoki bean affects gene expression of genes associated with cholesterol metabolism in rats. Exp. Biol. Med., 229, 787-792.

Henningsson, A. M., Bjorck, I. M. E., \& Nyman, E. M. G. L. (2002). Combinations of Indigestible Carbohydrates Affect Short-Chain Fatty Acid Formation in the Hindgut of Rats. J. Nutr., 132, 3098-3104.

Jenkins, D. J. A., Vuksan, C., Kendall, W. C., Wursch, P., Jeffcoat, R., Waring, S., ... Wong, E. (1998). Physiological effects of resistant starches on fecal bulk, short chain fatty acids, blood lipids and glycemic index. J. of the American College of Nutrition, 17(6), 609-616.

Kleessen, B., Stoof, G., Proll, J., Schmiedl, D., Noack, J., \& Blaut, M. (1997). Feeding resistant starch affects fecal and cecal microflora and short-chain fatty acids in rats. J. Anim. Sci., 75, 2453-2462.

Kurniawati, E. (2003). Pengaruh diet tinggi serat bekatul jagung (Zea mays L.) dan agar-agar terhadap profil lipid dan sifat digesta tikus Sprague Dawley. Tesis S2 Program Studi Ilmu Pangan, UGM, Yogyakarta.

Leng, S. L., Leeding, K. S., Gibson, P. G., \& Bach, L. A. (2001). Insulin-like growth factor-II renders LIM 2405 human kolon cancer cell resistant to butyrate-induce apoptosis: a potential for mechanism for kolon cancer cell survival in vivo. Carcinogenesis, 22(10), 1625-1631. http://dx.doi.org/10.1093/carcin/22.10.1625

Marsono, Y., Wiyono, P., \& Utama, Z. (2005). Indek glikemik produk olahan garut (Maranta arudinaceae Linn) dan uji sifat fungsionalnya pada model hewan coba. Laporan akhir RUSNAS Diversfikasi Pangan Pokok, Fakultas Teknologi Pertanian UGM Yogyakarta.

McOrist, A. L., Miller, R. B., Bird, A. R., Keogh, J. B., Noakes, M., Topping, D. L., \& Conlon, M. A. (2011). Fecal Butyrate Levels Vary Widely among Individuals but Are Usually Increased by a Diet High in Resistant Starch. J. Nutr., 141(5), 883-889. http://dx.doi.org/10.3945/jn.110.128504

Nugent, A. P. (2005). Health properties of resistant starch. Review. Britis Nutrition Foundation Nutrition Bulletin, 30, 27-54. http://dx.doi.org/10.1111/j.1467-3010.2005.00481.x

Sharp, R., \& Macfarlane, dan G. T. (2000). Chemostat enrichments of human feces with resistant starch are selective for adherent butyrate-producing clostridia at high dilution rates. Appl. Environ. Microbiol., 66(10), 4212-4221. http://dx.doi.org/10.1128/AEM.66.10.4212-4221.2000

Tester, R. F., Karkalas, J., \& Qi, X. (2004). Starch structure and digestibility enzyme-substrate relationship. World's Poultry Science Journal, 60, 186-195. http://dx.doi.org/10.1079/WPS20040014 